\title{
Helical muon beam cooling channel engineering design (Phase I)
}

\section{Cooperative Research and Development Agreement Final Report}

\section{CRADA Number: FRA-2011-0005}

\section{Fermilab Technical Contact: Alexander Zlobin}

Summary Report

7 August 2015 


\section{NOTICE}

This report was prepared as an account of work sponsored by an agency of the United States government. Neither the United States government nor any agency thereof, nor any of their employees, makes any warranty, express or implied, or assumes any legal liability or responsibility for the accuracy, completeness, or usefulness of any information, apparatus, product, or process disclosed, or represents that its use would not infringe privately owned rights. Reference herein to any specific commercial product, process, or service by trade name, trademark, manufacturer, or otherwise does not necessarily constitute or imply its endorsement, recommendation, or favoring by the United States government or any agency thereof. The views and opinions of authors expressed herein do not necessarily state or reflect those of the United States government or any agency thereof.

Available electronically at http://www.osti.gov/bridge

Available for a processing fee to U.S. Department of Energy and its contractors, in paper, from:

U.S. Department of Energy Office of Scientific and Technical Information

P.O. Box 62

Oak Ridge, TN 37831-0062

phone: 865.576 .8401

fax: 865.576.5728

email: mailto:reports@adonis.osti.gov

Available for sale to the public, in paper, from:

U.S. Department of Commerce

National Technical Information Service

5285 Port Royal Road

Springfield, VA 22161

phone: 800.553 .6847

fax: 703.605.6900

email: orders@ntis.fedworld.gov

online ordering: http://www.ntis.gov/ordering.htm 
In accordance with Requirements set forth in Article XI.A(3) of the CRADA document, this document is the final CRADA report, including a list of Subject Inventions, to be forwarded to the Office of Science and Technical Information as part of the commitment to the public to demonstrate results of federally funded research.

CRADA number: $\quad$ FRA-2011-0005

CRADA Title: $\quad$ Helical Muon Beam Cooling Channel Engineering Design

Parties to the Agreement: $\quad$ MUONS, Inc and Fermi Research Alliance, LLC

\section{Abstract of CRADA work:}

Develop a design for the integration of $805 \mathrm{MHz}$ RF cavities into a $10 \mathrm{~T}$ Nb3Sn based HCC test section. Several SBIR-STTR developed inventions will be combined in an innovative practical engineering solution for a muon cooling channel suitable for a muon collider or for highbrightness muon beams for other applications. Supported in part by DOE STTR grant application DE-SC0006266

\section{Summary of Research Results:}

The first phase of this project saw the development of a conceptual design for the integration of $805 \mathrm{MHz}$ RF cavities into a $10 \mathrm{~T} \mathrm{Nb3Sn}$ based HS test section. Two very novel ideas are required to realize the design. The first idea is the use of dielectric inserts in the RF cavities to make them smaller for a given frequency so that the cavities and associated plumbing easily fit inside the magnet cryostat. Calculations indicate that heat loads will be tolerable, while RF breakdown of the dielectric inserts will be suppressed by the pressurized hydrogen gas. The second new idea is the use of a multi-layer Nb3Sn helical solenoid. The technology demonstrations for the two aforementioned key components of a 10T, $805 \mathrm{MHz}$ HCC were proposed for Phase II. (See OSTI Technical Report 1266464 for final description of both Phase I and Phase II work.) This agreement was funded in part by DOE STTR award DE-FG02-11ER86492.

\section{Related Reports, Publications, and Presentations:}

FERMILAB-CONF-12-229-APC-TD, June 2012, Flanagan, G. et al, “Helical Muon Beam Cooling Channel Engineering Design"

PAC2013, Pasadena, CA, Flanagan, G. et al, "Helical Muon Beam Cooling Channel Engineering Design" (THPBA22) 
Johnson, Rolland. Helical muon beam cooling channel engineering design. United States: N. p., 2015.Web. doi:10.2172/1266464.

Subject Inventions listing:

None

Report Date: 7 August 2015

Technical Contact at Fermilab: Alexander Zlobin

This document contains NO confidential, protectable or proprietary information. 